\title{
Data report: sediment major element, minor element, and reactive iron and manganese data from the Okinawa Trough: IODP Expedition 331 Sites C0014 and C0017'
}

\author{
Jesse M. Muratli, ${ }^{2}$ Meghan R. Megowan, ${ }^{2}$ and James McManus ${ }^{2,} 3$
}

\section{Chapter contents}

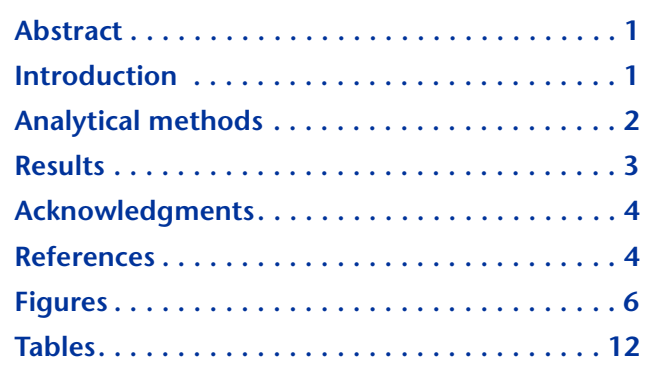

${ }^{1}$ Muratli, J.M., Megowan, M.R., and McManus, J., 2015. Data report: sediment major element, minor element, and reactive iron and manganese data from the Okinawa Trough: IODP Expedition 331 Sites $\mathrm{C} 0014$ and C0017. In Takai, K., Mottl, M.J., Nielsen, S.H., and the Expedition 331 Scientists, Proc. IODP, 331: Tokyo (Integrated Ocean Drilling Program Management International, Inc.). doi:10.2204/iodp.proc.331.202.2015 ${ }^{2}$ College of Earth, Ocean, and Atmospheric Sciences, Oregon State University, Corvallis OR 97330, USA.

3Present address: Department of Geosciences, University of Akron, Akron OH 44325, USA. jmcmanus@uakron.edu

\begin{abstract}
We present sediment solid-phase chemical data from Integrated Ocean Drilling Program Expedition 331 Sites C0014 and C0017, two sites with contrasting sediment chemistries. Results presented here include a suite of major and trace elements from whole-sediment digestions and sediments extracted using a selective leaching procedure for Fe and Mn. The sediment package at Site C0014 is chemically variable, displaying a wide range of concentrations for a number of major and trace elements. This sediment package has intervals rich in solid-phase $\mathrm{Mg}$, with values as high as 10-15 wt $\%$ between $\sim 30$ and 38 meters below seafloor (mbsf) and lower values at shallower depths and deeper than $\sim 40$ mbsf. This pattern is consistent with other expedition data, suggesting a sedimentary zone of active high-temperature alteration centered roughly between 30 and 40 mbsf. The upper sedimentary package is also rich in dithionate extractable iron, which decreases to low values by $\sim 30$ mbsf. Unlike iron, dithionate extractable $\mathrm{Mn}$ is relatively low in the upper $20-30 \mathrm{~m}$ of sediment, with some enrichment in the uppermost sediment package for Holes C0014G and C0014B. Below this region, however, a zone of enriched reactive and total $\mathrm{Mn}$ is centered just above $\sim 40 \mathrm{mbsf}$. In contrast to Site C0014, Site C0017 generally lacks the more pronounced chemical signatures apparent within the sediments, and many of the chemical signatures likely reflect the regional background hemipelagic sediment cover. There are, however, elevated levels of reactive Mn both in the upper $\sim 30 \mathrm{~m}$ and the bottom $\sim 50-75 \mathrm{~m}$ of sediment.
\end{abstract}

\section{Introduction}

During Integrated Ocean Drilling Program (IODP) Expedition 331, several sites were drilled within the Okinawa Trough region where the Iheya North hydrothermal field is located. This report focuses on two sites located east of the main hydrothermal vent field, which is an active hydrothermal venting region (Takai et al., 2011; see the "Expedition 331 summary" chapter [Expedition 331 Scientists, 2011a]).

Site C0014 is located $\sim 450 \mathrm{~m}$ east of the main vent field and is a dynamic environment with pore fluid chemistry suggestive of a hemipelagic sediment cover overlying a diagenetically and hydrothermally altered sediment package containing volcanic sediments, hydrothermally altered muds, and pumiceous sediments 
(Takai et al., 2011). Temperatures increase from bottom water values to $\sim 145^{\circ}$ at 47 mbsf with an abrupt increase to $>200^{\circ} \mathrm{C}$ at 50 mbsf (see the "Site C0014" chapter [Expedition 331 Scientists, 2011b]). For Hole C0014G, the hole with the most continuous sampling through the sediment column and the hole for which we have the most complete data set, the upper $\sim 20 \mathrm{~m}$ is rich in dissolved sulfate with a decrease to near zero at $\sim 30$ mbsf (Takai et al., 2011). Within this upper, sulfate-rich package, dissolved $\mathrm{Mg}$ is close to the seawater value with a decrease to values $<5 \mathrm{mM}$ by $\sim 40$ mbsf (Takai et al., 2011).

Site C0017 is located farther east, roughly $1.6 \mathrm{~km}$ from the Iheya hydrothermal vent field. This site has the deepest penetration of the holes drilled during the expedition. Similar to Site C0014, Site C0017 is primarily a site of mixed sediment types with thick hemipelagic mud and various volcaniclastic sediment types. Temperature measurements indicate that the sediment column reaches $\sim 90^{\circ} \mathrm{C}$ by $\sim 150.7$ mbsf (see the "Site C0017" chapter [Expedition 331 Scientists, 2011c]). This site, however, lacks the dramatic and larger scale hydrothermal alteration seen at Site C0014. Consistent with this contention, the pore fluid chemistry of the uppermost $25-35 \mathrm{~m}$ is dominated by more typical hemipelagic diagenetic reactions (Takai et al., 2011). Below this depth, lowtemperature reactions continue to dominate the pore fluid chemistry (Takai et al., 2011).

For both of these sites, lateral fluid flow has been inferred (Takai et al., 2011). From the perspective of this report, it is important to note that Site C0014 exhibits clear evidence for active high-temperature alteration, whereas Site C0017 does not. Both of these systems also have physical and chemical features that imply a dynamic and perhaps nonsteadystate environment where any possible fluid flow is likely to be three dimensional (Takai et al., 2011).

\section{Analytical methods Total digestion methods}

The details of our sediment digestion methods are outlined in Muratli et al. (2012). Briefly, dried and ground sediment samples were digested using a combination of inorganic acids $\left(\mathrm{HCl}, \mathrm{HNO}_{3}\right.$, and $\left.\mathrm{HF}\right)$ in a CEM MARS-5 microwave oven (CEM Corp., Matthews, NC). Postdigestion evaporation within the system was accomplished utilizing the MicroVap accessory. Following sample dilution with $5 \% \mathrm{HNO}_{3}$ into preweighed $10 \mathrm{~mL}$ HDPE bottles (this dilution is somewhat modified from Muratli et al., 2010a, 2010b, 2012), samples were heated in an analog block heater for $\sim 24 \mathrm{~h}$. Prior work identified the ne- cessity of this step to redissolve any remnant fluoride-metal complexes that, although they might not be visually apparent in the digestion matrix, were found to impact analytical results (e.g., Muratli et al., 2010b, 2012).

\section{ICP-OES}

Samples for major elements (Tables T1, T2) were run on a Leeman Laboratories Prodigy inductively coupled plasma-optical emission spectrometer (ICPOES) at the W.M. Keck Collaboratory at Oregon State University (USA). This instrument is capable of two viewing modes, axial and radial, and the various elements were run in one mode or the other. Table T1 also presents the specific emission wavelengths utilized for each element. Samples and standards were diluted twenty-fold with $1 \%$ quartz-distilled nitric acid. Repeated runs of the standard curve monitored instrumental drift, and for those elements influenced by drift we applied a correction factor. The reported data represent the mean of three replicate analyses for each element in each tube except in instances where we have results from multiple sample digestions. In this case, the mean is the average of the two results. Uncertainties for samples that were not digested in duplicate are derived from two sources: (1) the regression uncertainty, which is calculated using the standard error of the regression, and (2) the internal uncertainty calculated from the standard deviation of the three replicate analyses. These two uncertainties are combined as the square root of the sum of squares.

\section{ICP-MS}

Trace constituents were analyzed on a Thermo X-Series II inductively coupled plasma-mass spectrometer (ICP-MS), also at the W.M. Keck Collaboratory. IPC-MS results can drift over the course of the day's run, and drift is corrected by spiking each sample with an internal standard solution. This solution consisted of $250 \mathrm{ng} / \mathrm{mL}$ Be and $50 \mathrm{ng} / \mathrm{mL}$ each of Rh and $\mathrm{Bi}$ or just $50 \mathrm{ng} / \mathrm{mL}$ of $\mathrm{Rh}$ and Bi. Measured counts throughout the run were corrected to the value of the first blank run of the day. Because of the varied matrix in these samples, $\mathrm{Rh}$ was used as the lone internal reference standard for the calculation of results. Although using only a single element for drift correction is less than optimal, samples had varying amounts of $\mathrm{Be}$ and $\mathrm{Bi}$, thus making reliable concentration results difficult to obtain. Sample dilutions varied with concentration, but samples were diluted with $1 \% \mathrm{HNO}_{3}$. Sample uncertainties were calculated using the same approach employed for the ICP-OES results. 
We used the following isotope masses to calculate concentrations: ${ }^{66} \mathrm{Zn},{ }^{98} \mathrm{Mo},{ }^{111} \mathrm{Cd},{ }^{114} \mathrm{Cd},{ }^{133} \mathrm{Cs},{ }^{146} \mathrm{Nd}$, ${ }^{185} \mathrm{Re},{ }^{187} \mathrm{Re}$, and ${ }^{238} \mathrm{U}$. Multiple analyte masses have interferences; thus, some of the analytes above were used to estimate these interferences. For ${ }^{114} \mathrm{Cd}$ we measured ${ }^{117} \mathrm{Sn}$ to assess the level of interference of ${ }^{114} \mathrm{Sn}$ :

$$
{ }^{114} \mathrm{Cd}_{\text {corr }}=\left({ }^{114} \mathrm{Cd}_{\text {meas }}\right)-0.0859375 \times{ }^{117} \mathrm{Sn} .
$$

An additional interference from ${ }^{114} \mathrm{MoO}$ on ${ }^{114} \mathrm{Cd}$ is estimated from the Mo results and the estimated $\mathrm{MoO} / \mathrm{Mo}$ formation ratio. For this work, we only report results from the ${ }^{114} \mathrm{Cd}$ analyses because we are more confident in the correction for this Cd mass. For ${ }^{187} \mathrm{Re}$, a series of solutions containing $\mathrm{Yb}$ were analyzed and a $\mathrm{YbO} / \mathrm{Yb}$ ratio was calculated. Counts of ${ }^{171} \mathrm{Yb}$ were then used to estimate the interference on ${ }^{187} \mathrm{Re}$. ${ }^{185} \mathrm{Re}$ has an interference by $\mathrm{TmO}$; for this reason, we generally use ${ }^{187}$ Re to calculate Re concentrations. However, at higher Re concentrations (and higher Re dilutions) this interference is small, and we use ${ }^{185}$ Re for estimating concentrations.

\section{Dithionite extractions of $\mathrm{Fe}$ and $\mathrm{Mn}$}

To determine "reactive" iron and manganese, we employed a single-step dithionite extraction at $60^{\circ} \mathrm{C}$ (Mehra and Jackson, 1960; Kostka and Luther, 1994; McManus et al., 2012; Roy et al., 2013). We used approximately $0.25 \mathrm{~g}$ of dried ground sediment to which we added $\sim 10 \mathrm{~mL}$ of dithionite reagent. $\mathrm{pH}$ is buffered using a sodium acetate, sodium citrate solution (Roy et al., 2013). These extractions are generally thought to dissolve amorphous Fe oxides, some crystalline $\mathrm{Fe}$ oxides, and acid volatile sulfides (Kostka and Luther, 1994; Poulton and Canfield, 2005). However, for many of the samples digested here it is possible that the sediments are sufficiently reducing to the point where sulfides are the dominant reactive phase; thus, any future interpretations of the data presented here require caution regarding the specific phase being extracted using this procedure. Unlike Fe, this procedure is not well calibrated for Mn (McManus et al., 2012).

\section{Quality control}

To access accuracy and precision, we report values from replicate digestions of a PACS- 2 standard and an in-house laboratory sediment standard (Tables T2, T3, T4). This latter standard is a continental margin sediment standard from the Chile margin ( $\mathrm{Mu}-$ ratli et al., 2010a, 2010b). We also report our own laboratory's long-term average for these materials (Tables T2, T3). Finally, we redigested/reanalyzed a number of samples, which are indicated within the data tables. Because the samples that we analyzed as part of this study are quite unlike either of the reference material matrixes, the reproducibility of our reference materials may not be an accurate measure of the true reproducibility of the samples. Generally speaking, however, the samples did indeed reproduce quite well, with one exception. As noted in Table $\mathrm{T} 3$, the $\mathrm{Zn}$ and $\mathrm{Cd}$ results from one duplicate sample (331-C0014B-3H-5, 20-30 cm) did not agree, and the results for these two analytes (for one of the duplicates) were higher than all other samples measured during this study. We did not obtain an accurate concentration estimate for these two analytes because the concentrations were above our highest standard and we did not reanalyze this sample. We report here a lower concentration for the duplicate, for which we have a more analytically robust measure of these two analytes. We suspect that either the sample was somehow contaminated or it was not homogeneous. We do note, however, that other elements do show agreement between these two duplicates.

In the case of our Fe and Mn extractions, we also extracted these same sediment standards and report the data in Table T4. These values are not standardized and can thus only be used as a measure of technique precision. Furthermore, many of the reported results are the result of duplicate sediment extractions and analyses, and for these samples the average values are reported ( \pm 1 standard deviation).

\section{Results}

The solid phase $\mathrm{Mg}$ from Site C0014 (Fig. F1A) is highly variable, with low values in the uppermost sediment package and higher values between 30 and 40 mbsf. We show here the dissolved $\mathrm{Mg}$ profiles from the cores in which we have corresponding solid-phase analyses and which show the expected depletion of $\mathrm{Mg}$ relative to the seawater value within the zone of high $\mathrm{Mg}$ concentrations (Fig. F1B). The $\mathrm{Ca} / \mathrm{Al}$ ratios generally show lower values than those expected for average upper continental crust, with the exception of the uppermost samples (Fig. F2A). The K/Al ratios are quite variable, with low values near the zone of high $\mathrm{Mg} / \mathrm{Al}$ and at slightly shallower depths for some of the samples (Fig. F2B, F2C). Generally speaking, the upper sediment package from core to core can be variable, and this variability was noted for the pore fluid results from this site (Takai et al., 2011). Below $40 \mathrm{mbsf}, \mathrm{K} / \mathrm{Al}$ values are slightly enriched relative to average upper continental crust (Fig. F2B). Ba/Al is also generally lower than upper continental crust values, with the exception of 
the uppermost sediment package and at 12-15 mbsf (Fig. F2B). Fe/Al is generally enriched in the uppermost 40 mbsf, whereas $\mathrm{Fe}_{\mathrm{R}} / \mathrm{Fe}_{\mathrm{T}}$ enrichments are generally confined to the upper 20 mbsf (Fig. F3A, F3B). Below these depths, Fe/Al is depleted relative to average upper crust values and the $\mathrm{Fe}_{\mathrm{R}} / \mathrm{Fe}_{\mathrm{T}}$ ratio approaches zero, meaning that very little of the iron is extractable at these depths. The upper sediment package is depleted in $\mathrm{Mn}$, but a broad elevated $\mathrm{Mn}$ / $\mathrm{Al}$ maximum is centered between $\sim 30$ and $50 \mathrm{mbsf}$ (Fig. F3C, F3D). There is some suggestion of elevated $\mathrm{Mn}_{\mathrm{R}} / \mathrm{Mn}_{\mathrm{T}}$ in this region, particularly with respect to the upper sediment package; however, much of the data set suggests $\mathrm{Mn}_{\mathrm{R}}$ concentrations are $\sim 10 \%$ or less of the total Mn.

In contrast to the data from Site C0014, the data from Site C0017 has much smaller variability in the sedimentary $\mathrm{Mg}$ contents, with few samples significantly enriched over the value for the upper continental crust (Fig. F4A). This observation is consistent with the dissolved profile, which exhibits little deviation from the ambient seawater value (Fig. F4B). $\mathrm{Ca} / \mathrm{Al}$ ratios in the upper $\sim 40 \mathrm{~m}$ are elevated over the background, and deeper samples have values that hover near the upper continental crust ratio (Fig. F5A). The $\mathrm{K}$ to $\mathrm{Al}$ ratios are relatively constant, as are the $\mathrm{Ba}$ to $\mathrm{Al}$ ratios (Fig. $\mathrm{F} 5 \mathrm{~B}, \mathrm{~F} 5 \mathrm{C}$ ). Fe to $\mathrm{Al}$ ratios are generally slightly enriched relative to the upper continental crust value but vary little with depth (Fig. F6A). The $\mathrm{Fe}_{R}$ to $\mathrm{Fe}_{T}$ ratios are higher on average relative to Site C0014, but no particular pattern is apparent in the data (Fig. F6B). Mn to Al ratios also do not vary significantly compared to Site $\mathrm{C} 0014$ and generally scatter about the crustal ratio, with the average value slightly below that ratio (Fig. F6C). The $\mathrm{Mn}_{\mathrm{R}}$ to $\mathrm{Mn}_{\mathrm{T}}$ ratio has a distinct minimum below $50 \mathrm{mbsf}$ with values increasing with depth (Fig. F6D).

\section{Acknowledgments}

This research used samples and/or data provided by the Integrated Ocean Drilling Program (IODP). IODP is sponsored by the U.S. National Science Foundation (NSF) and participating countries under management of IODP Management International, Inc. (IODP-MI). Financial support was provided by the U.S. Science Support Program (USSSP) for shorebased analyses.

\section{References}

Expedition 331 Scientists, 2011a. Expedition 331 summary. In Takai, K., Mottl, M.J., Nielsen, S.H., and the
Expedition 331 Scientists, Proceedings of the Integrated Ocean Drilling Program, 331: Tokyo (Integrated Ocean Drilling Program Management International, Inc.). http://dx.doi.org/10.2204/iodp.proc.331.101.2011

Expedition 331 Scientists, 2011b. Site C0014. In Takai, K., Mottl, M.J., Nielsen, S.H., and the Expedition 331 Scientists, Proceedings of the Integrated Ocean Drilling Program, 331: Tokyo (Integrated Ocean Drilling Program Management International, Inc.).

http://dx.doi.org/10.2204/iodp.proc.331.104.2011

Expedition 331 Scientists, 2011c. Site C0017. In Takai, K., Mottl, M.J., Nielsen, S.H., and the Expedition 331 Scientists, Proceedings of the Integrated Ocean Drilling Program, 331: Tokyo (Integrated Ocean Drilling Program Management International, Inc.).

http://dx.doi.org/10.2204/iodp.proc.331.107.2011

Kostka, J.E., and Luther, G.W., III, 1994. Partitioning and speciation of solid phase iron in saltmarsh sediments. Geochimica et Cosmochimica Acta, 58(7):1701-1710. http://dx.doi.org/10.1016/0016-7037(94)90531-2

McManus J., Berelson, W.M., Severmann, S., Johnson, K.S., Hammond, D.E., Roy, M., and Coale, K.H., 2012. Benthic manganese fluxes along the Oregon-California continental shelf and slope. Continental Shelf Research, 43:71-85.

http://dx.doi.org/10.1016/j.csr.2012.04.016

Mehra, O.P., and Jackson, M.L., 1960. Iron oxide removal from soils and clays by a dithionite-citrate system buffered with sodium bicarbonate. Clays and Clay Minerals, 7:317-327.

http://dx.doi.org/10.1346/CCMN.1958.0070122

Muratli, J.M., Chase, Z., McManus, J., and Mix, A., 2010a. Ice-sheet control of continental erosion in central and southern Chile $\left(36^{\circ}-41^{\circ} \mathrm{S}\right)$ over the last 30,000 years. Quaternary Science Reviews, 29(23-24):3230-3239. http://dx.doi.org/10.1016/j.quascirev.2010.06.037

Muratli, J.M., Chase, Z., Mix, A.C., and McManus, J., 2010b. Increased glacial-age ventilation of the Chilean margin by Antarctic Intermediate Water. Nature Geoscience, 3:23-26. http://dx.doi.org/10.1038/ngeo715

Muratli, J.M., McManus, J., Mix, A., and Chase, Z., 2012. Dissolution of fluoride complexes following microwaveassisted hydrofluoric acid digestion of marine sediments. Talanta, 89:195-200. http://dx.doi.org/10.1016/j.talanta.2011.11.081

Poulton, S.W., and Canfield, D.E., 2005. Development of a sequential extraction procedure for iron: implications for iron partitioning in continentally derived particulates. Chemical Geology, 214(3-4):209-221. http://dx.doi.org/10.1016/j.chemgeo.2004.09.003

Roy, M., McManus, J., Goñi, M.A., Chase, Z., Borgeld, J.C., Wheatcroft, R.A., Muratli, J.M., Megowan, M.R., and Mix, A., 2013. Reactive iron and manganese distributions in seabed sediments near small mountainous rivers off Oregon and California (USA). Continental Shelf Research, 54:67-69.

http://dx.doi.org/10.1016/j.csr.2012.12.012 
Rudnick, R.L., and Gao, S., 2004. Composition of the continental crust. In Rudnick, R.L. (Ed.), Treatise on Geochemistry (Vol 3): The Crust. Holland, H.D., and Turekian, K.K. (Series Eds.): Oxford, UK (Elsevier), 1-64. http://dx.doi.org/10.1016/B0-08-043751-6/03016-4

Takai, K., Mottl, M.J., Nielsen, S.H.H., and the IODP Expedition 331 Scientists, 2012. IODP Expedition 331: strong and expansive subseafloor hydrothermal activi- ties in the Okinawa Trough. Scientific Drilling, 13:19-27. http://dx.doi.org/10.2204/iodp.sd.13.03.2011

Initial receipt: 30 June 2013

Acceptance: 5 June 2015

Publication: 9 October 2015

MS 331-202 
Figure F1. Plots of (A) Mg/Al and (B) pore fluid dissolved Mg, Holes C0014B, C0014D, and C0014G. Dashed lines $=($ A) upper continental crust ratio (Rudnick and Gao, 2004), (B) seawater value.

A

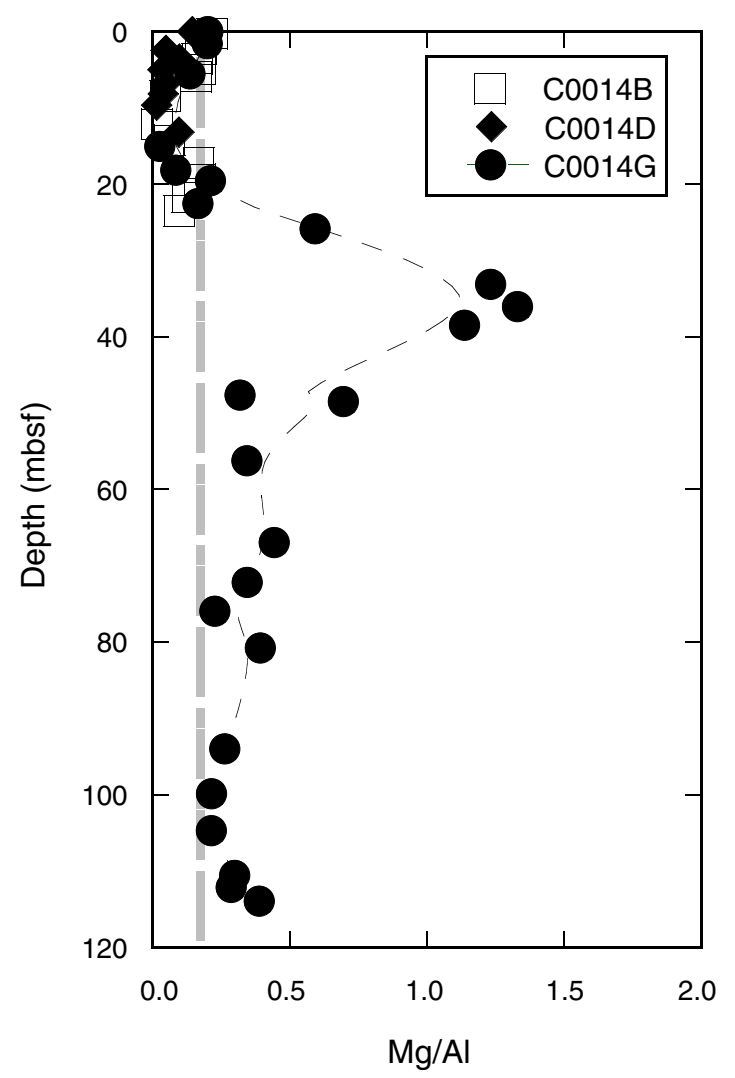

B

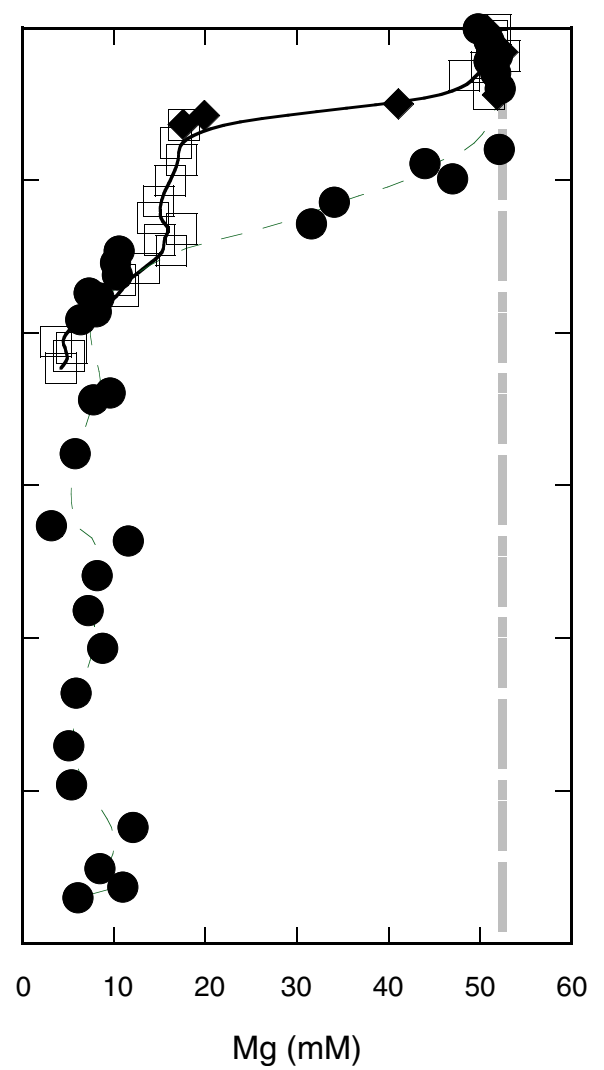


Figure F2. Plots of (A) Ca/Al, (B) K/Al, and (C) Ba/Al, Holes C0014B, C0014D, and C0014G. Dashed lines = upper continental crust ratio (Rudnick and Gao, 2004).

A

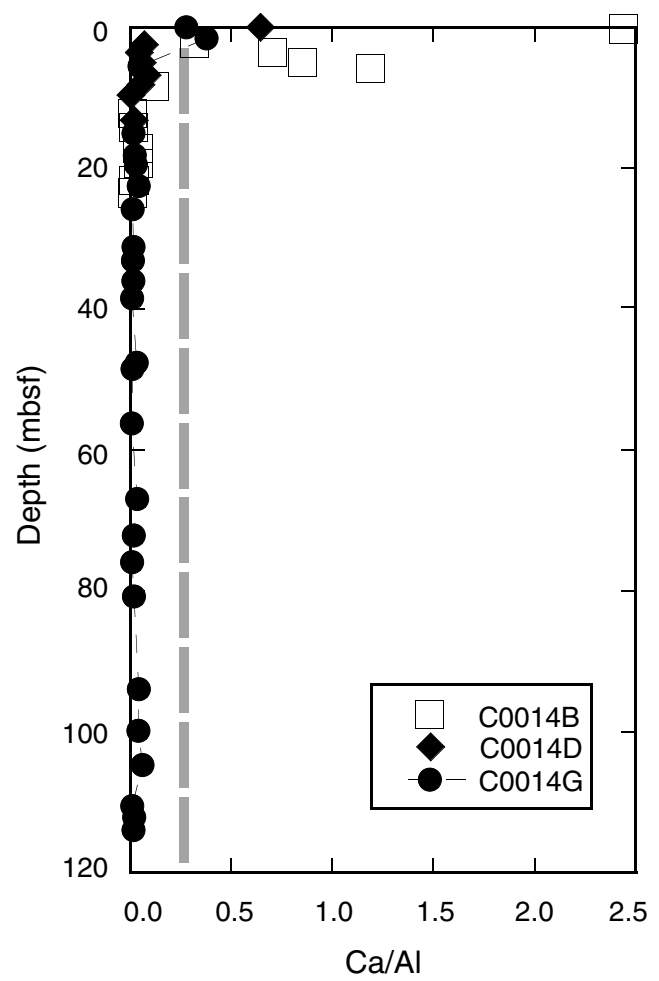

B

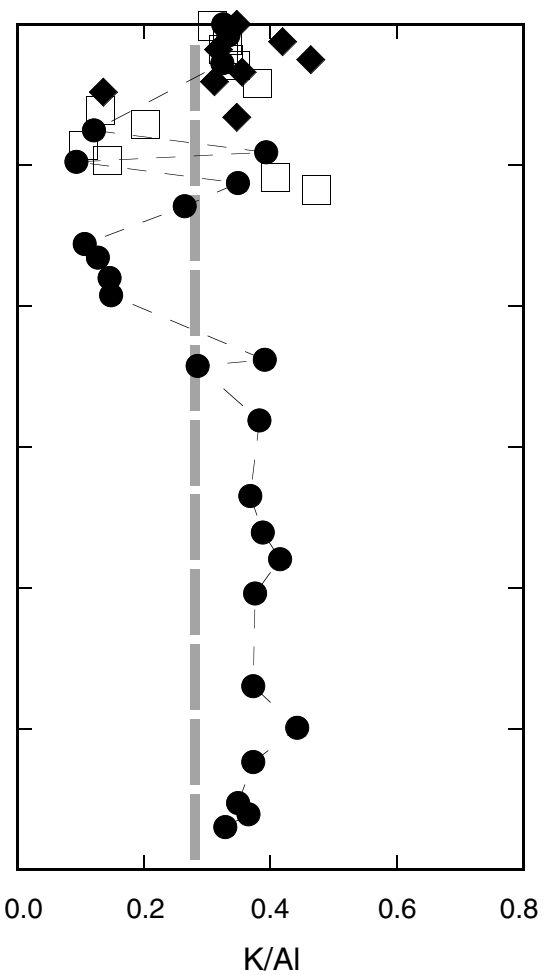

C

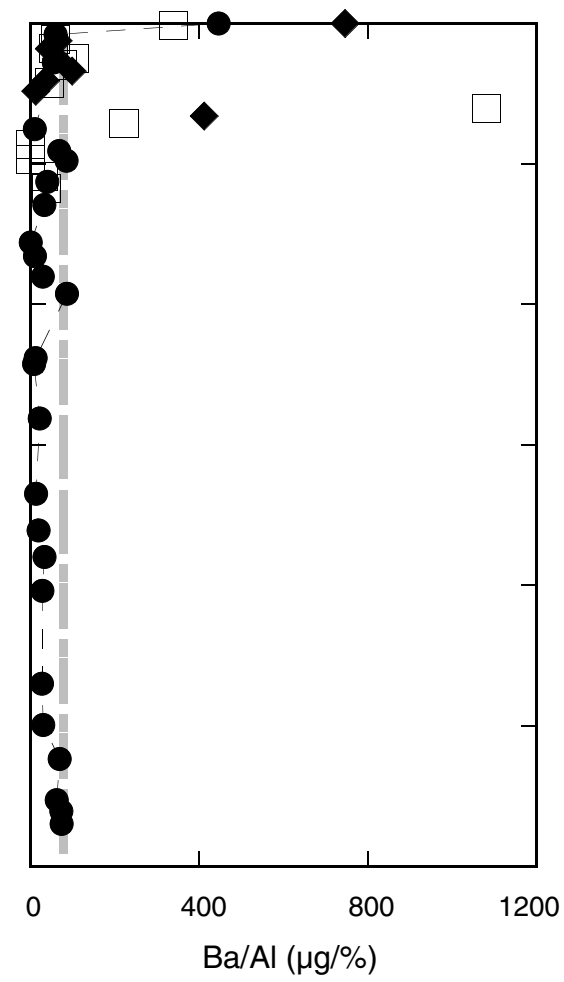


Figure F3. Plots of (A) Fe/Al, (B) $\mathrm{Fe}_{\mathrm{R}} / \mathrm{Fe}_{\mathrm{T}}$, (C) $\mathrm{Mn} / \mathrm{Al}$, and (D) $\mathrm{Mn}_{\mathrm{R}} / \mathrm{Mn}_{\mathrm{T}}$, Holes C0014B, C0014D, and C0014G. Dashed lines $=$ upper continental crust ratio (Rudnick and Gao, 2004).

A

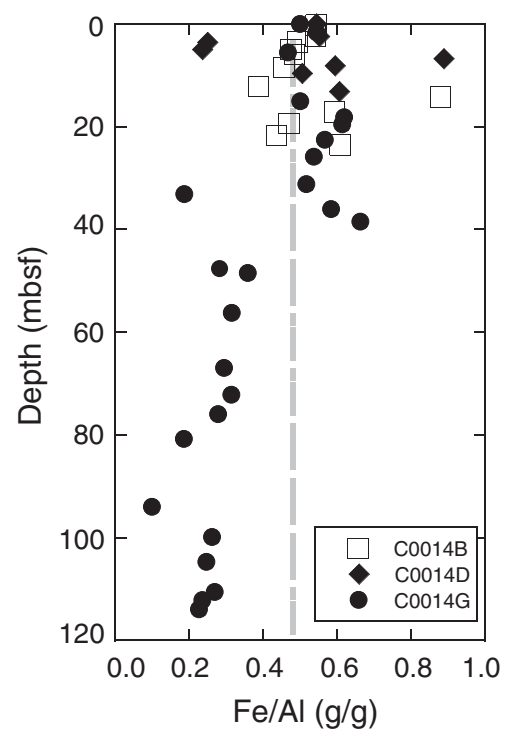

B

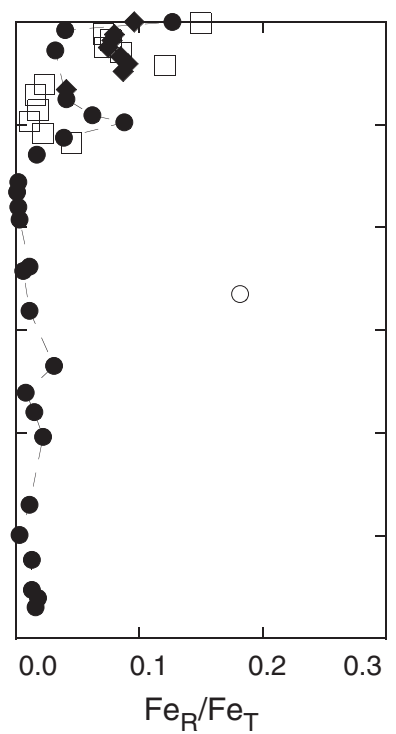

C

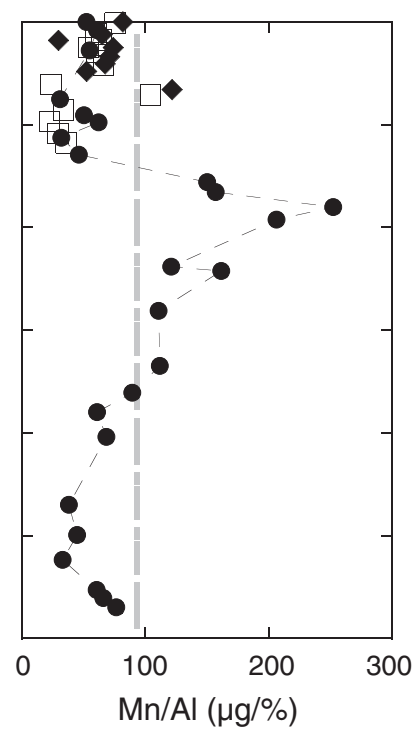

D

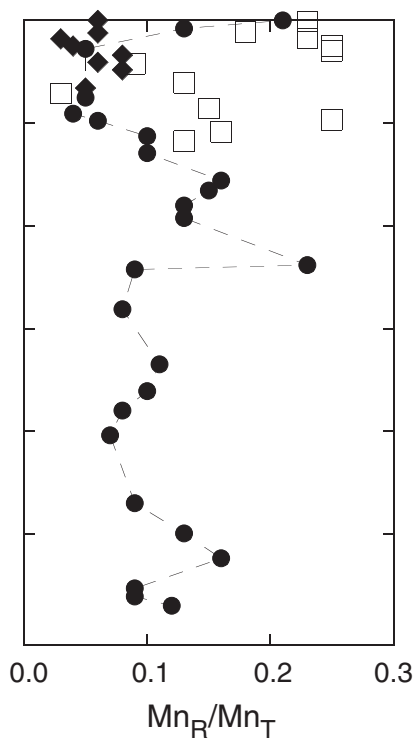


Figure F4. Plots of (A) Mg/Al and (B) pore fluid dissolved Mg, Holes C0017A-C0017D. Dashed lines = (A) upper continental crust ratio (Rudnick and Gao, 2004), (B) seawater value.

A

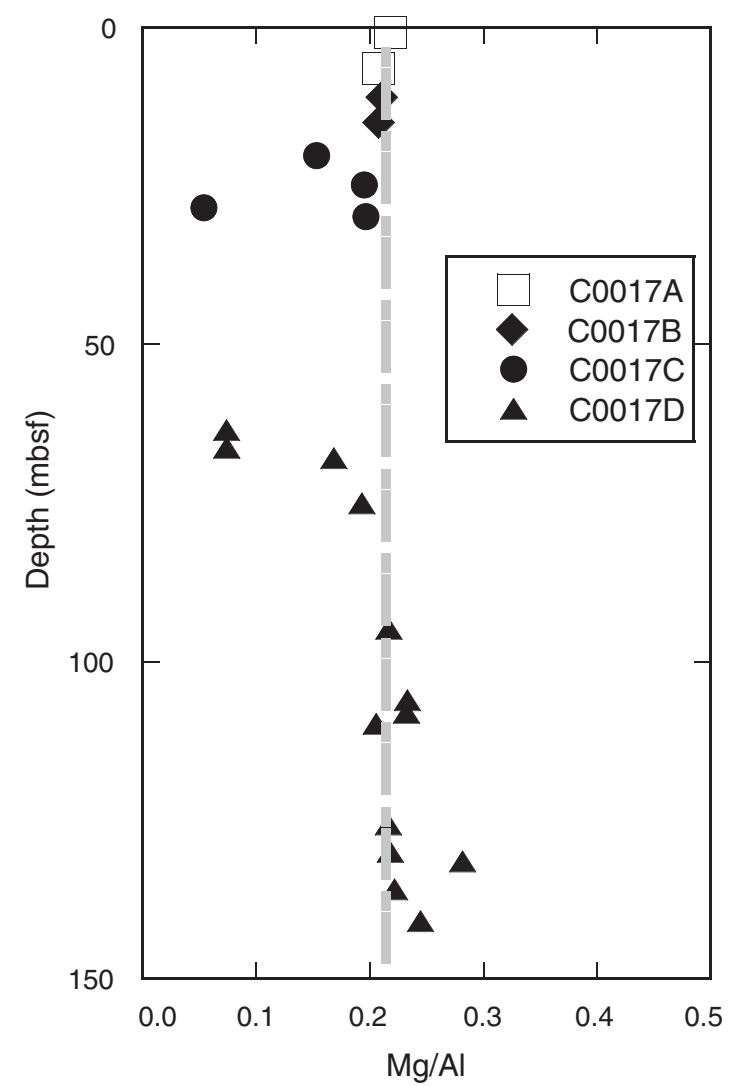

B

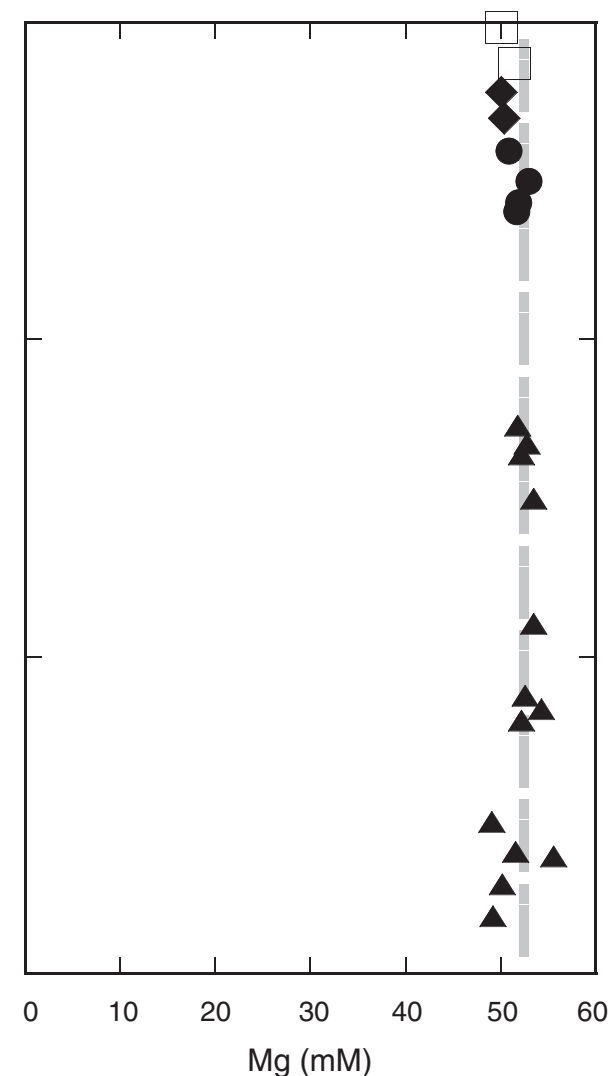


Figure F5. Plots of (A) Ca/Al, (B) K/Al, and (C) Ba/Al, Holes C0017A-C0017D. Dashed lines = upper continental crust ratio (Rudnick and Gao, 2004).

A

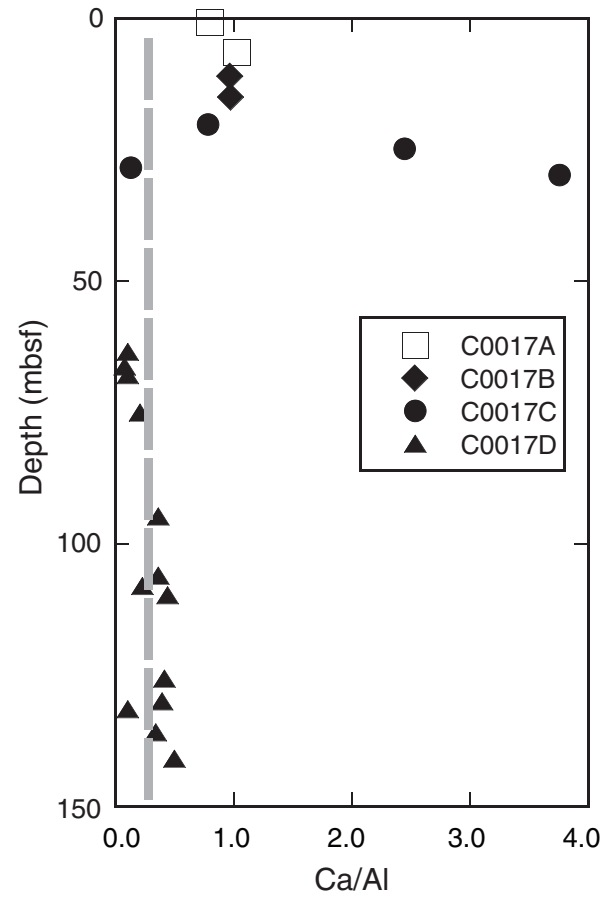

B

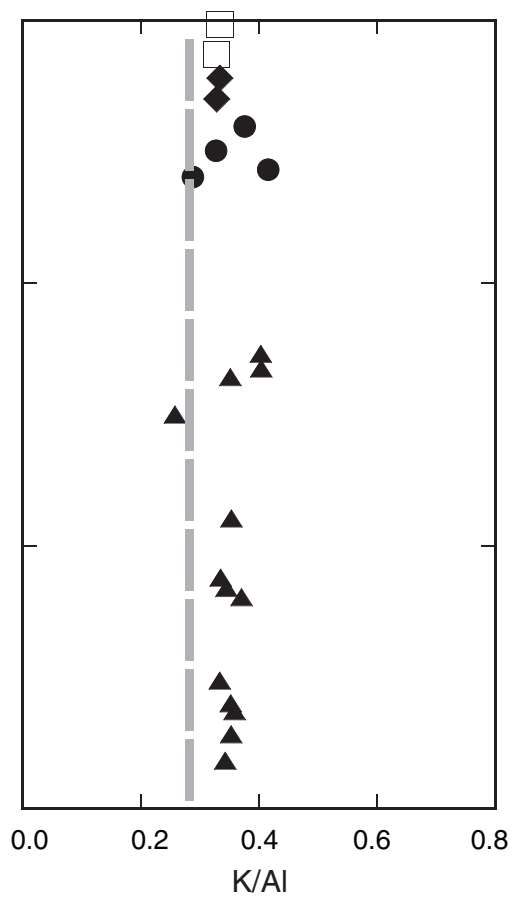

C

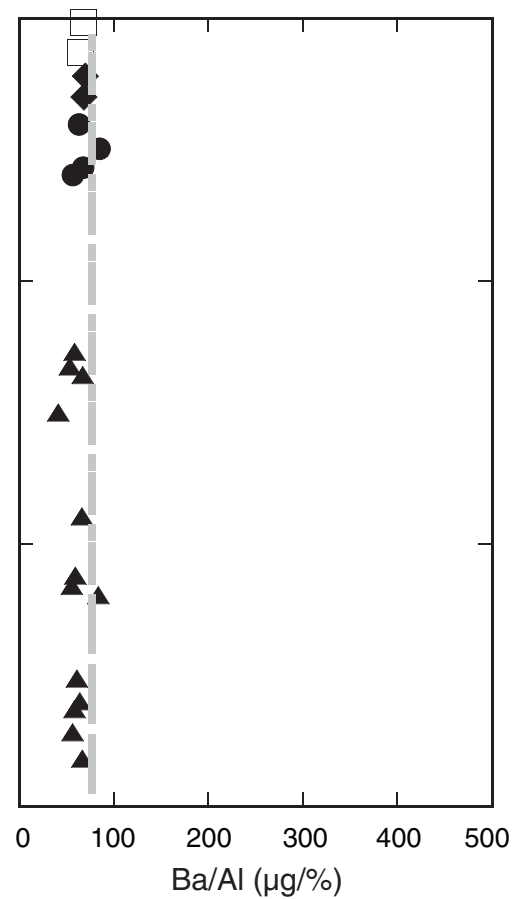


Figure F6. Plots of (A) Fe/Al, (B) $\mathrm{Fe}_{\mathrm{R}} / \mathrm{Fe}_{\mathrm{T}}$, (C) $\mathrm{Mn} / \mathrm{Al}$, and (D) $\mathrm{Mn}_{\mathrm{R}} / \mathrm{Mn}_{\mathrm{T}}$, Holes C0017A-C0017D. Dashed lines = upper continental crust ratio (Rudnick and Gao, 2004).

A

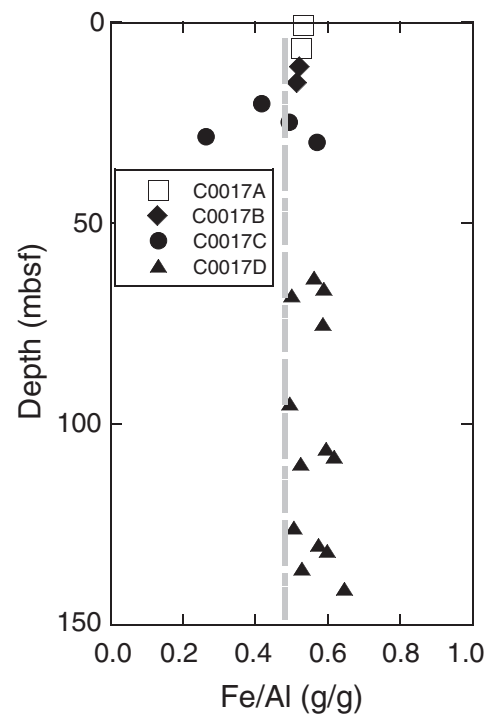

B

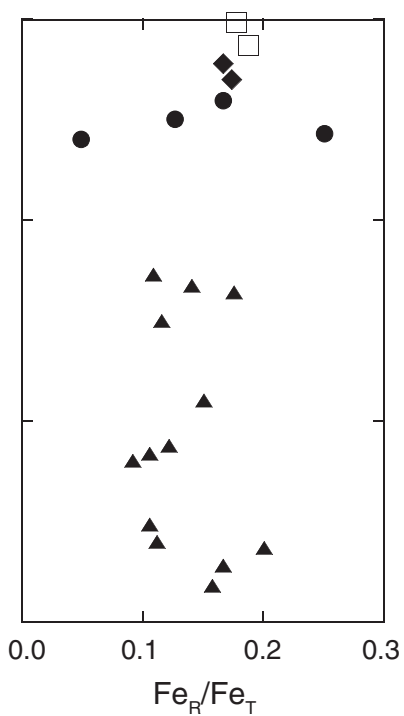

C

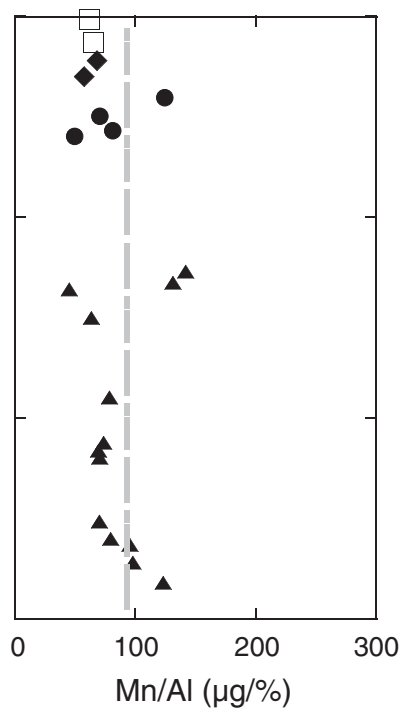

D

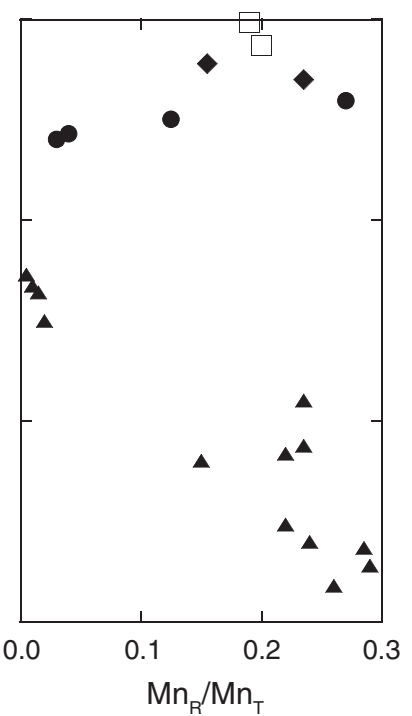


Table T1. ICP-OES run specifications.

\begin{tabular}{lcl}
\hline Element & Line $(\mathrm{nm})$ & View \\
\hline $\mathrm{Al}$ & 396.152 & Radial \\
$\mathrm{Ba}$ & 455.403 & Radial \\
$\mathrm{Ca}$ & 317.933 & Radial \\
$\mathrm{Cu}$ & 324.754 & Axial \\
$\mathrm{Fe}$ & 259.940 & Radial \\
$\mathrm{K}$ & 766.491 & Radial \\
$\mathrm{Mg}$ & 279.078 & Axial \\
$\mathrm{Mn}$ & 257.610 & Radial \\
$\mathrm{Na}$ & 589.592 & Radial \\
$\mathrm{Sr}$ & 407.771 & Radial \\
$\mathrm{Ti}$ & 334.941 & Radial \\
$\mathrm{V}$ & 292.401 & Axial \\
$\mathrm{Zn}$ & 206.200 & Axial \\
$\mathrm{Zr}$ & 343.823 & Axial \\
\hline
\end{tabular}

Table T2. ICP-OES sediment results, Expedition 331. This table is available in an oversized format.

Table T3. ICP-MS sediment results, Expedition 331. (Continued on next page.)

\begin{tabular}{|c|c|c|c|c|c|c|c|c|c|c|c|c|c|c|c|}
\hline $\begin{array}{l}\text { Core, section, } \\
\text { interval }(\mathrm{cm})\end{array}$ & $\begin{array}{l}\text { Depth } \\
\text { (mbsf) }\end{array}$ & $\begin{array}{c}Z n \\
(\mu \mathrm{g} / \mathrm{g})\end{array}$ & \pm & $\begin{array}{c}\text { Mo } \\
(\mu \mathrm{g} / \mathrm{g})\end{array}$ & \pm & $\begin{array}{c}\mathrm{Cd} \\
(\mu \mathrm{g} / \mathrm{g})\end{array}$ & \pm & $\begin{array}{c}\text { Cs } \\
(\mu \mathrm{g} / \mathrm{g})\end{array}$ & \pm & $\begin{array}{c}\mathrm{Nd} \\
(\mu \mathrm{g} / \mathrm{g})\end{array}$ & \pm & $\begin{array}{c}\mathrm{Re} \\
(\mathrm{ng} / \mathrm{g})\end{array}$ & \pm & $\underset{(\mu \mathrm{g} / \mathrm{g})}{U}$ & \pm \\
\hline \multicolumn{16}{|l|}{ 331-C0014B- } \\
\hline $1 \mathrm{H}-1,25-35^{*}$ & 0.25 & 222 & 9 & 3.7 & 0.6 & 0.24 & 0.01 & 6.4 & 0.1 & 22.4 & 0.4 & 2.6 & 0.4 & 3.9 & 0.2 \\
\hline $1 \mathrm{H}-2,100-110$ & 2.32 & 184 & 1 & 27.7 & 0.3 & 0.78 & 0.02 & 12.7 & 0.1 & 32.4 & 0.9 & 16.2 & 0.8 & 8.5 & 0.5 \\
\hline $1 \mathrm{H}-3,92-105$ & 3.54 & 108 & 1 & 2.10 & 0.04 & 0.29 & 0.02 & 12.0 & 0.1 & 30.2 & 0.9 & 6.6 & 0.7 & 4.6 & 0.5 \\
\hline $1 \mathrm{H}-4,100-110$ & 4.95 & 110 & 1 & 1.21 & 0.03 & 0.28 & 0.01 & 17.6 & 0.1 & 29.5 & 0.8 & 7.8 & 0.7 & 5.5 & 0.5 \\
\hline $1 \mathrm{H}-5,65-75$ & 5.91 & 101 & 1 & 0.93 & 0.02 & 0.31 & 0.02 & 20.0 & 0.1 & 28.0 & 0.9 & 8.7 & 0.9 & 5.5 & 0.5 \\
\hline $2 \mathrm{H}-3,10-20$ & 8.46 & 106 & 1 & 140 & 2 & 3.58 & 0.03 & 8.5 & 0.1 & 21.6 & 0.9 & $55^{\ddagger}$ & 6 & 37.4 & 0.9 \\
\hline $2 \mathrm{H}-7,40-50$ & 12.18 & $981^{\dagger}$ & 12 & 193 & 3 & & & 10.1 & 0.1 & 7.2 & 0.9 & $75^{\ddagger}$ & 5 & 247 & 25 \\
\hline $2 \mathrm{H}-10,20-30$ & 14.26 & $790^{\dagger}$ & 13 & 289 & 3 & 3.99 & 0.05 & 12.3 & 0.1 & 7 & 1 & $195^{\ddagger}$ & 6 & 51.5 & 0.9 \\
\hline $3 \mathrm{H}-2,52-62$ & 17.21 & 42.7 & 0.8 & 28.4 & 0.3 & 0.12 & 0.02 & 12.0 & 0.1 & 119 & 1 & 11 & 1 & 27.0 & 0.4 \\
\hline $3 \mathrm{H}-5,20-30^{*}$ & 19.39 & 197 & 1 & 22.5 & 0.3 & 0.60 & 0.02 & 10.2 & 0.2 & 35 & 1 & 5.6 & 0.0 & 5.7 & 0.1 \\
\hline 3H-7, 89-99 & 21.74 & $1003^{\dagger}$ & 13 & 6.19 & 0.08 & 4.31 & 0.02 & 11.2 & 0.1 & 50.6 & 0.9 & 2.5 & 0.7 & 9.8 & 0.5 \\
\hline $3 \mathrm{H}-9,67.5-77.5$ & 23.52 & 139 & 1 & 4.66 & 0.02 & 0.48 & 0.02 & 14.5 & 0.1 & 42.6 & 0.9 & 4 & 1 & & \\
\hline \multicolumn{16}{|l|}{ 331-C0014D- } \\
\hline $1 \mathrm{H}-1,2-5$ & 0.02 & 186 & 1 & 76.6 & 0.7 & 4.43 & 0.03 & 8.8 & 0.1 & 22.3 & 0.9 & $96^{\ddagger}$ & 4 & 17.6 & 0.5 \\
\hline $1 \mathrm{H}-2,108-110^{*}$ & 2.48 & 122 & 2 & 130.4 & 0.9 & & & 4.5 & 0.1 & 11. & 0.2 & $155^{\ddagger}$ & 3 & 26.1 & 0.6 \\
\hline $1 \mathrm{H}-3,80-82$ & 3.61 & 78 & 1 & 4.85 & 0.07 & 0.07 & 0.02 & 15.8 & 0.1 & 35.6 & 0.9 & 3.0 & 0.7 & 88 & 1 \\
\hline $1 \mathrm{H}-4,80-82$ & 5.03 & 74 & 1 & 11.2 & 0.1 & 0.18 & 0.02 & 1.9 & 0.1 & 29 & 1 & & & & \\
\hline $2 \mathrm{H}-1,30-32$ & 6.80 & 96 & 1 & 170 & 2 & 4.17 & 0.04 & 3.4 & 0.1 & 8.1 & 0.9 & $114^{\ddagger}$ & 7 & 29 & 1 \\
\hline $2 \mathrm{H}-2,30-32$ & 8.18 & $381^{\dagger}$ & 13 & 810 & 12 & & & 2.8 & 0.1 & 26.1 & 0.9 & $536^{\ddagger}$ & 15 & 80 & 1 \\
\hline $2 \mathrm{H}-3,37-39$ & 9.66 & $330^{\dagger}$ & 13 & 546 & 2 & 2.97 & 0.10 & 3.4 & 0.1 & 5 & 1 & $433^{\ddagger}$ & 6 & 201 & 4 \\
\hline $2 \mathrm{H}-6,60-62$ & 13.21 & $649^{\dagger}$ & 13 & 39.9 & 0.3 & 0.64 & 0.02 & 18.6 & 0.1 & 23.8 & 0.9 & 22.5 & 0.8 & 19.0 & 0.4 \\
\hline \multicolumn{16}{|l|}{ 331-C0014G- } \\
\hline $1 \mathrm{H}-1,0-2$ & 0.00 & 239 & 2 & 5.34 & 0.03 & 0.57 & 0.01 & 10.8 & 0.2 & 30.8 & 0.6 & 13.4 & 0.5 & 4.1 & 0.3 \\
\hline $1 \mathrm{H}-2,20-22$ & 1.58 & 119 & 1 & 10.51 & 0.09 & 0.31 & 0.02 & 13.9 & 0.1 & 33.0 & 0.6 & 7.6 & 0.6 & 6.3 & 0.3 \\
\hline $1 \mathrm{H}-5,10-12$ & 5.56 & 127 & 1 & 78.4 & 0.6 & 0.78 & 0.01 & 23.1 & 0.1 & 29.1 & 0.6 & 91 & 2 & 30.7 & 0.6 \\
\hline $2 \mathrm{H}-5,45-47$ & 15.05 & 196 & 1 & 125.4 & 0.7 & 0.48 & 0.03 & 7.3 & 0.2 & 6.7 & 0.6 & 83 & 2 & 181 & 8 \\
\hline $2 \mathrm{H}-7,80-82$ & 18.17 & 100 & 1 & 0.87 & 0.04 & 0.24 & 0.02 & 16.8 & 0.2 & 25.5 & 0.6 & 7.8 & 0.7 & 5.2 & 0.3 \\
\hline $3 \mathrm{H}-2,26-28$ & 19.55 & 232 & 2 & 42.5 & 0.3 & 0.40 & 0.01 & 5.2 & 0.2 & 88.4 & 0.7 & 11 & 1 & 6.1 & 0.3 \\
\hline $3 \mathrm{H}-5,27-29$ & 2 & 114 & 1 & 13.1 & 0.1 & 0.12 & 0.01 & 15.5 & 0.2 & 54.8 & 0.6 & 5.3 & 0.7 & 18.2 & 0.4 \\
\hline $3 \mathrm{H}-8,116-118$ & 25.85 & 93 & 1 & 2.14 & 0.04 & 0.08 & 0.02 & 6.3 & 0.2 & 25.7 & 0.5 & BDL & & 2.1 & 0.3 \\
\hline $4 \mathrm{H}-5,80-82^{*}$ & 31.21 & 50 & 1 & 13.2 & 0.2 & BDL & & 2.3 & 0.1 & 52 & 1 & 6.2 & 0.5 & 5.3 & 0.0 \\
\hline $4 \mathrm{H}-7,70-72$ & 33.13 & 95 & 1 & 5.55 & 0.05 & 0.09 & 0.02 & 2.3 & 0.2 & 21.2 & 0.5 & 2.6 & 0.8 & 4.9 & 0.3 \\
\hline $4 \mathrm{H}-10,60-62$ & 36.05 & $321^{\dagger}$ & 12 & 9.29 & 0.05 & 0.59 & 0.01 & 2.1 & 0.2 & 63.3 & 0.5 & BDL & & 14.8 & 0.3 \\
\hline $5 \mathrm{H}-3,45-47$ & 38.49 & 139 & 1 & 27.0 & 0.3 & $\mathrm{BDL}$ & & 1.1 & 0.2 & 48.5 & 0.6 & $\mathrm{BDL}$ & & 5.1 & 0.3 \\
\hline $6 \mathrm{H}-2,38-40$ & 47.64 & 49 & 1 & 4.48 & 0.03 & BDL & & 1.8 & 0.2 & 44.5 & 0.5 & $\mathrm{BDL}$ & & 3.4 & 0.3 \\
\hline $6 \mathrm{H}-3,80-82$ & 48.51 & 92 & 1 & 5.87 & 0.05 & $\mathrm{BDL}$ & & 2.0 & 0.2 & 44.5 & 0.7 & $\mathrm{BDL}$ & & 3.2 & 0.3 \\
\hline $9 X-2,64-66$ & 56.25 & 45 & 1 & 6.44 & 0.05 & BDL & & 1.1 & 0.2 & 31.0 & 0.5 & 3.0 & 0.6 & 5.7 & 0.3 \\
\hline $13 \mathrm{~T}-1,28-30$ & 66.98 & 89 & 1 & 18.1 & 0.1 & $\mathrm{BDL}$ & & 1.3 & 0.2 & 40.0 & 0.5 & 9.4 & 0.8 & 22.6 & 0.4 \\
\hline $14 \mathrm{~T}-2,51-53^{*}$ & 72.19 & 64 & 2 & 24 & 1 & $\mathrm{BDL}$ & & 1.2 & 0.0 & 40.0 & 0.4 & 8.5 & 0.3 & 19.1 & 0.1 \\
\hline 16T-1, 7-9 & & 79 & 1 & 10.2 & 0.2 & BDL & & 1.5 & 0.2 & 35.1 & 0.7 & 5.9 & 0.7 & 8.2 & 0.3 \\
\hline $17 \mathrm{~T}-2,20-22$ & 80.81 & 78 & 1 & 4.16 & 0.05 & $\mathrm{BDL}$ & & 1.9 & 0.2 & 84.6 & 0.6 & 5.4 & 0.7 & 8.3 & 0.3 \\
\hline
\end{tabular}


Table T3 (continued).

\begin{tabular}{|c|c|c|c|c|c|c|c|c|c|c|c|c|c|c|c|}
\hline $\begin{array}{l}\text { Core, section, } \\
\text { interval }(\mathrm{cm})\end{array}$ & $\begin{array}{l}\text { Depth } \\
\text { (mbsf) }\end{array}$ & $\begin{array}{c}\mathrm{Zn} \\
(\mu \mathrm{g} / \mathrm{g})\end{array}$ & \pm & $\begin{array}{c}\text { Mo } \\
(\mu \mathrm{g} / \mathrm{g})\end{array}$ & \pm & $\begin{array}{c}C d \\
(\mu \mathrm{g} / \mathrm{g})\end{array}$ & \pm & $\begin{array}{c}C s \\
(\mu \mathrm{g} / \mathrm{g})\end{array}$ & \pm & $\begin{array}{c}\mathrm{Nd} \\
(\mu \mathrm{g} / \mathrm{g})\end{array}$ & \pm & $\begin{array}{c}\operatorname{Re} \\
(\mathrm{ng} / \mathrm{g})\end{array}$ & \pm & $\underset{(\mu \mathrm{g} / \mathrm{g})}{U}$ & \pm \\
\hline 20T-1, 30-32 & 94.00 & 26 & 1 & 4.95 & 0.07 & $\mathrm{BDL}$ & & 0.8 & 0.2 & 31.9 & 0.6 & 2.9 & 0.7 & 3.1 & 0.3 \\
\hline $21 \mathrm{H}-3,79-81$ & 99.90 & 48 & 1 & 9.5 & 0.1 & $\mathrm{BDL}$ & & 1.1 & 0.2 & 63 & 1 & 3.3 & 0.9 & 6.4 & 0.3 \\
\hline $23 X-1,5-8$ & 104.75 & 43 & 1 & 3.92 & 0.03 & $\mathrm{BDL}$ & & 0.6 & 0.2 & 31.3 & 0.6 & $\mathrm{BDL}$ & & 2.3 & 0.3 \\
\hline $24 \mathrm{~T}-2,90-92$ & 110.60 & 43 & 1 & 3.42 & 0.04 & $\mathrm{BDL}$ & & 0.8 & 0.2 & 36.9 & 0.7 & $\mathrm{BDL}$ & & 2.5 & 0.3 \\
\hline $24 \mathrm{~T}-4,49.5-51.5$ & 112.18 & 48 & 1 & 3.55 & 0.03 & $\mathrm{BDL}$ & & 0.9 & 0.2 & 39.0 & 0.6 & 2.2 & 0.8 & 3.2 & 0.3 \\
\hline $25 \mathrm{~T}-1,28.5-30.5$ & 113.99 & 61 & 1 & 4.05 & 0.07 & $\mathrm{BDL}$ & & 0.8 & 0.2 & 30.9 & 0.6 & 2.8 & 0.7 & 3.4 & 0.3 \\
\hline \multicolumn{16}{|l|}{ 331-C0017A- } \\
\hline $1 \mathrm{H}-1,80-90$ & 0.80 & 104 & 1 & 1.02 & 0.03 & 0.32 & 0.01 & 11.1 & 0.1 & 28.7 & 0.9 & 4.6 & 0.5 & 4.1 & 0.5 \\
\hline $1 \mathrm{H}-5,88-98$ & 6.52 & 108 & 1 & 0.53 & 0.03 & 0.35 & 0.01 & 10.4 & 0.1 & 28.8 & 0.9 & 11.5 & 0.6 & 5.0 & 0.5 \\
\hline \multicolumn{16}{|l|}{ 331-C0017B- } \\
\hline $1 \mathrm{H}-2,85-95$ & 11.03 & 134 & 1 & 0.63 & 0.02 & 0.31 & 0.01 & 10.6 & 0.1 & 29.0 & 0.9 & 5.7 & 0.7 & 3.9 & 0.5 \\
\hline $1 \mathrm{H}-5,70-80$ & 15.01 & 98 & 1 & 0.64 & 0.02 & 0.46 & 0.01 & 11.2 & 0.1 & 27.9 & 0.9 & 20 & 1 & 5.5 & 0.5 \\
\hline \multicolumn{16}{|l|}{ 331-C0017C- } \\
\hline $1 \mathrm{H}-2,60-70$ & 20.26 & 81 & 1 & 1.66 & 0.02 & 0.22 & 0.01 & 6.7 & 0.1 & 28.9 & 0.9 & 5.1 & 0.5 & 3.3 & 0.5 \\
\hline $1 \mathrm{H}-5,115-125$ & 24.87 & 72 & 1 & 1.27 & 0.02 & 0.60 & 0.01 & 5.6 & 0.1 & 21.0 & 0.9 & 25.6 & 0.9 & 7.9 & 0.5 \\
\hline $2 \mathrm{H}-1,65-75$ & 28.45 & 70 & 1 & 4.06 & 0.04 & 0.13 & 0.01 & 3.1 & 0.1 & 29.3 & 0.9 & $\mathrm{BDL}$ & & 2.4 & 0.5 \\
\hline $2 \mathrm{H}-2,65-75$ & 29.85 & 73 & 1 & 0.28 & 0.02 & 0.12 & 0.01 & 4.6 & 0.1 & 24.0 & 0.9 & $\mathrm{BDL}$ & & 1.9 & 0.5 \\
\hline \multicolumn{16}{|l|}{ 331-C0017D- } \\
\hline $1 \mathrm{H}-3,80-90^{*}$ & 63.55 & 117 & 0 & 1.84 & 0.16 & 0.19 & 0.00 & 3.2 & 0.1 & 34.4 & 1.1 & $\mathrm{BDL}$ & & 1.8 & 0.1 \\
\hline $1 \mathrm{H}-5,80-90$ & 66.30 & 116 & 1 & 2.13 & 0.03 & 0.18 & 0.01 & 3.3 & 0.2 & 34.8 & 0.6 & $\mathrm{BDL}$ & & 1.7 & 0.3 \\
\hline $1 \mathrm{H}-6,110-120$ & 67.98 & 73 & 1 & 0.51 & 0.03 & $\mathrm{BDL}$ & & 6.7 & 0.2 & 30.5 & 0.6 & $\mathrm{BDL}$ & & 2.0 & 0.3 \\
\hline $2 \mathrm{H}-5,30-40$ & 75.08 & 111 & 1 & 0.53 & 0.03 & 0.10 & 0.01 & 8.9 & 0.2 & 28.0 & 0.6 & 7.9 & 0.8 & 3.5 & 0.3 \\
\hline $6 X-1,66-76$ & 94.86 & 75 & 1 & 0.75 & 0.03 & 0.09 & 0.01 & 8.4 & 0.2 & 30.6 & 0.6 & $\mathrm{BDL}$ & & 2.4 & 0.3 \\
\hline 7H-2, 112-122 & 106.16 & 92 & 1 & 1.18 & 0.03 & 0.19 & 0.01 & 10.3 & 0.2 & 31.6 & 0.6 & $\mathrm{BDL}$ & & 2.8 & 0.3 \\
\hline $7 \mathrm{H}-4,42-52$ & 108.12 & 96 & 1 & 2.20 & 0.04 & 0.15 & 0.01 & 11.3 & 0.2 & 31.3 & 0.7 & 2.0 & 0.5 & 2.8 & 0.3 \\
\hline $7 \mathrm{H}-5,80-90^{*}$ & 109.85 & 55 & 1 & 1.57 & 0.20 & 0.10 & 0.00 & 5.4 & 0.1 & 28.0 & 1.9 & 2.8 & 0.6 & 1.6 & 0.2 \\
\hline $9 X-5,25-35$ & 125.72 & 83 & 1 & 0.91 & 0.03 & 0.15 & 0.01 & 9.1 & 0.2 & 35.1 & 0.6 & 2.1 & 0.6 & 2.5 & 0.3 \\
\hline $9 X-8,75-90$ & 130.04 & 83 & 1 & 1.39 & 0.04 & 0.12 & 0.01 & 9.5 & 0.2 & 33.6 & 0.6 & BDL & & 2.8 & 0.3 \\
\hline $10 \mathrm{X}-1,88-102$ & 131.58 & 94 & 1 & 1.23 & 0.03 & 0.15 & 0.01 & 12.2 & 0.2 & 35.4 & 0.6 & 2.3 & 0.6 & 3.1 & 0.3 \\
\hline $10 X-4,80-90$ & 135.95 & 104 & 1 & 0.87 & 0.03 & 0.16 & 0.01 & 13.8 & 0.2 & 38.9 & 0.6 & $\mathrm{BDL}$ & & 3.2 & 0.3 \\
\hline $11 X-1,80-90$ & 141.00 & 80 & 1 & 1.16 & 0.03 & 0.15 & 0.01 & 8.5 & 0.2 & 33.0 & 0.6 & $\mathrm{BDL}$ & & 2.3 & 0.3 \\
\hline \multicolumn{16}{|l|}{ Reference materials } \\
\hline PACS-2 & & 369 & 10 & 5.7 & 0.2 & 2.16 & 0.06 & 2.40 & 0.07 & 18.5 & 0.4 & 6.1 & 0.3 & 2.7 & 0.1 \\
\hline Reference value & & 364 & 12 & 5.4 & 0.1 & 2.11 & 0.08 & & & & & & & (3) & \\
\hline $\begin{array}{l}\text { Long-term } \\
\text { average }\end{array}$ & & 395 & 31 & 6.8 & 1.9 & 2.14 & 0.08 & & & & & 6.3 & 0.4 & 2.5 & 0.1 \\
\hline $\begin{array}{l}\text { Laboratory } \\
\text { standard }\end{array}$ & & 84 & 1 & 1.8 & 0.1 & 0.45 & 0.01 & 5.24 & 0.07 & 19.4 & 0.4 & 14.5 & 0.6 & 3.4 & 0.2 \\
\hline Long-term average & & 89 & 7 & 1.9 & 0.1 & 0.45 & 0.01 & & & & & 14.7 & 0.6 & 3.4 & 0.1 \\
\hline \multicolumn{4}{|c|}{ Detection limit (approximate) } & & & 0.045 & & & & & & 2.0 & & & \\
\hline
\end{tabular}

* = digested in duplicate. $\dagger=$ analyzed using ICP-OES; $\mathrm{Zn}$ reference material results are for ICP-OES. $\ddagger=$ analyzed at a larger dilution factor than others; therefore, no oxide correction was applied. For Sample 331-C0014B-3H-5, 20-30 cm, we disregarded a high Zn and Cd value from one duplicate digestion. These samples were not rerun to ascertain accurate concentrations, but in each case they would have had the highest concentrations measured during this study $(\mathrm{Zn} \sim 3800 \mu \mathrm{g} / \mathrm{g}$ and $\mathrm{Cd} \sim 10 \mu \mathrm{g} / \mathrm{g})$. For Sample 331-C0017D-7H-5, 80-90 cm, one Re value was below the detection limit (BDL) and one was just above; we report the value above the detection limit. 
Table T4. Reactive iron and manganese results, Expedition 331. (Continued on next page.)

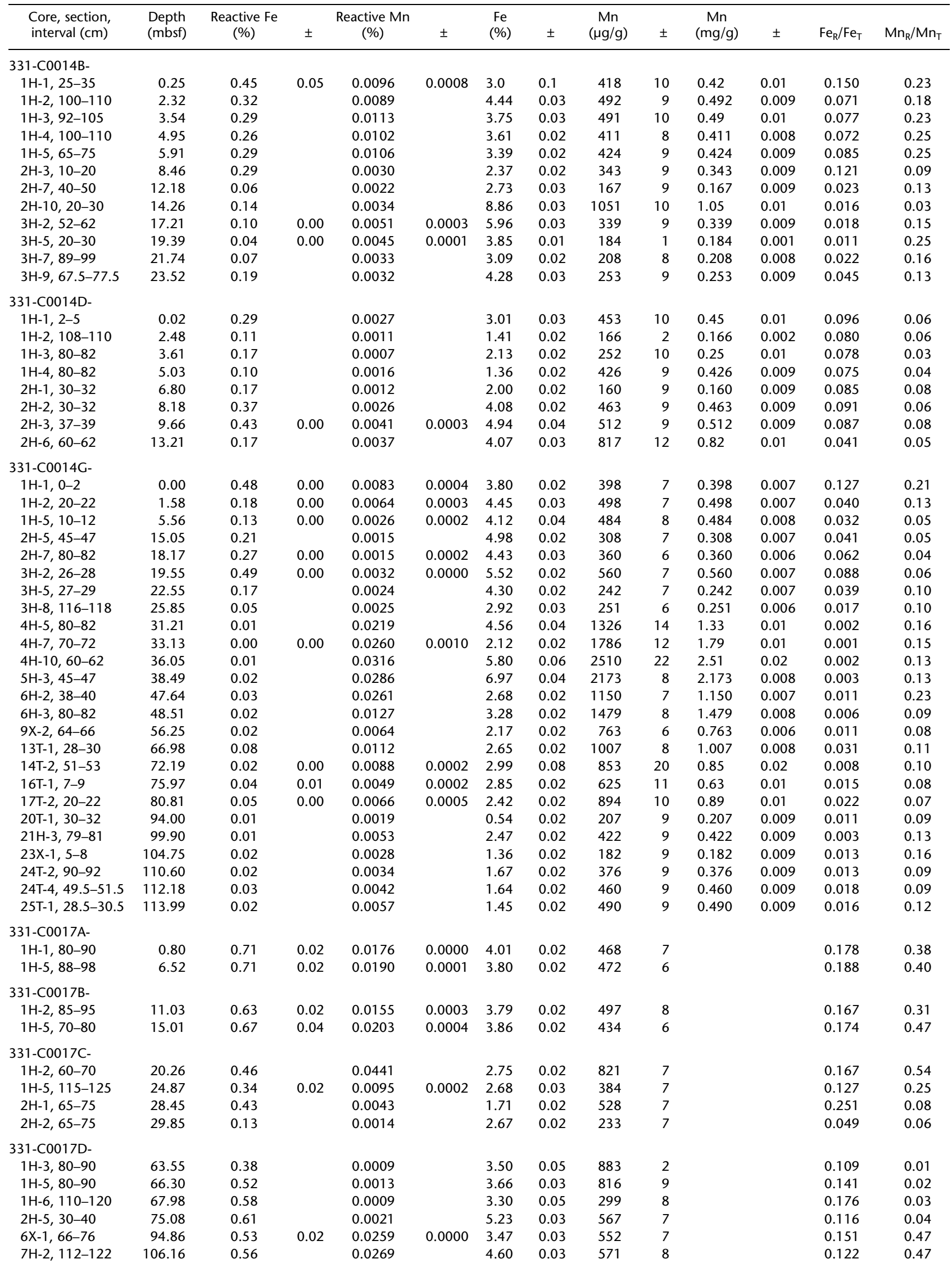


Table T4 (continued).

\begin{tabular}{|c|c|c|c|c|c|c|c|c|c|c|c|c|c|}
\hline $\begin{array}{l}\text { Core, section, } \\
\text { interval }(\mathrm{cm})\end{array}$ & $\begin{array}{l}\text { Depth } \\
\text { (mbsf) }\end{array}$ & $\begin{array}{c}\text { Reactive Fe } \\
\text { (\%) }\end{array}$ & \pm & $\begin{array}{l}\text { Reactive Mn } \\
(\%)\end{array}$ & \pm & $\begin{array}{l}\mathrm{Fe} \\
(\%)\end{array}$ & \pm & $\begin{array}{c}M n \\
(\mu g / g)\end{array}$ & \pm & $\begin{array}{c}\mathrm{Mn} \\
(\mathrm{mg} / \mathrm{g})\end{array}$ & \pm & $\mathrm{Fe}_{\mathrm{R}} / \mathrm{Fe}_{\mathrm{T}}$ & $\mathrm{Mn}_{\mathrm{R}} / \mathrm{Mn}_{\mathrm{T}}$ \\
\hline 7H-4, 42-52 & 108.12 & 0.51 & 0.02 & 0.0242 & 0.0002 & 4.87 & 0.03 & 549 & 7 & & & 0.106 & 0.44 \\
\hline 7H-5, 80-90 & 109.85 & 0.27 & & 0.0119 & & 2.99 & 0.01 & 402 & 9 & & & 0.092 & 0.30 \\
\hline $9 X-5,25-35$ & 125.72 & 0.41 & & 0.0235 & & 3.84 & 0.04 & 534 & 9 & & & 0.106 & 0.44 \\
\hline $9 X-8,75-90$ & 130.04 & 0.47 & & 0.0277 & & 4.19 & 0.04 & 581 & 7 & & & 0.112 & 0.48 \\
\hline $10 X-1,88-102$ & 131.58 & 1.00 & 0.01 & 0.0455 & 0.0002 & 4.95 & 0.03 & 792 & 9 & & & 0.201 & 0.57 \\
\hline $10 X-4,80-90$ & 135.95 & 0.80 & 0.01 & 0.0515 & 0.0001 & 4.79 & 0.02 & 889 & 8 & & & 0.167 & 0.58 \\
\hline $11 X-1,80-90$ & 141.00 & 0.68 & & 0.0426 & & 4.33 & 0.03 & 826 & 7 & & & 0.158 & 0.52 \\
\hline PACS-2 sediment & & 0.81 & 0.03 & 0.0030 & 0.0002 & & & & & & & & \\
\hline Laboratory standard & & 0.99 & 0.10 & 0.0025 & 0.0002 & & & & & & & & \\
\hline
\end{tabular}

